\title{
Improving the Accessibility of Federal Graduate Research Awards in Canada
}

\author{
$\underline{\text { Sivani Baskaran }}^{1,2^{*}}$, Dhanyasri Maddiboina ${ }^{1,3^{*}}$, Jina J.Y.

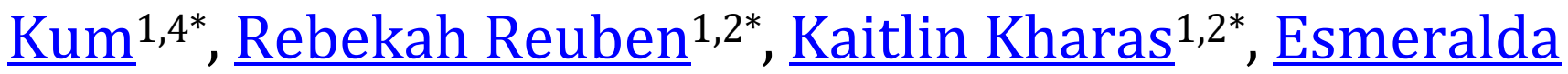 \\ Bukuroshi $^{1,2^{*}}$, Isabella Lim ${ }^{1,2+}$, Bipin Kumar Badri \\ Narayanan ${ }^{1,5+}$
}

1Toronto Science Policy Network, Toronto, ON, Canada

2University of Toronto, Toronto, ON, Canada

${ }_{3}^{3}$ McMaster University, Hamilton, ON, Canada

${ }^{4}$ Western University, London, ON, Canada

5 University of New Brunswick, Fredericton, NB, Canada

${ }^{*}$ Contributions towards writing, research and reviewing

+Contributions towards research and reviewing.

DOI hyperlink: https://doi.org/10.38126/ISPG180405

Corresponding author: sivanibaskaran1@gmail.com

Keywords: funding; research; early career researchers; graduate students; Canada; EDI

Executive Summary: Canadian federal graduate research awards provide graduate students with support that impacts both their experience during their degree and their future career progression. Obtaining federal funding during graduate education qualifies students for additional awards, provides financial security, and increases their research independence. However, the number and value of awards have remained unchanged for almost two decades and the evaluation and eligibility criteria are not designed to encourage applications from students from historically underrepresented groups (URGs). The three federal research funding agencies (the Tri-Agency) have recently released an Equity, Diversity, and Inclusion (EDI) Action Plan to better support early-career individuals from these groups, with a commitment to "identify and address barriers to equitable participation of members from underrepresented groups" (Initiative 1.2.2) and increase participation of URGs in the postsecondary research system (Objective 2). In this memo, we propose three changes to broaden the eligibility and evaluation of federal student awards, as well as increase and standardize the award values. Ultimately, these recommendations will reduce the barriers faced by URGs in applying for and obtaining these awards in a manner not currently addressed by the TriAgency's EDI plan.

\section{Introduction}

Graduate students are an integral part of research and innovation in Canada. Federal scholarships provide awarded graduate students with financial security and independence, along with greater control over their research direction (SPE 2021; CIHR 2016). In addition, these awards increase a student's chance at future awards (NSERC 2020) and can impact a student's potential in obtaining tenure track positions (van den Besselaar and Sandström 2015).
However, the chances of receiving a federal scholarship are not equal for all applicants. Previous research has found that female and visible minority applicants are significantly less likely to be awarded research funding compared to male and white applicants by the US National Institute of Health and Canadian Institutes of Health Research (CIHR) (Ginther et al. 2011; Witteman et al. 2019). Further, women, Indigenous peoples, persons with disabilities, and visible minorities lack 
representation in both award and application rates for several major Canadian funding opportunities (Canada Research Coordinating Committee 2020). Data from the 2006 and 2016 Canadian census shows that women and visible minorities are underrepresented in doctoral programs (Table 1), and the percentage of women, Indigenous peoples, and visible minorities holding university faculty positions is disproportionate to the Canadian population (Government of Canada 2018).

In Canada, major governmental scholarships are managed and distributed by three federal research funding agencies (the Tri-Agency): Natural Sciences and Engineering Research Council (NSERC), Social Sciences and Humanities Research Council (SSHRC), and CIHR (Table 2). The Tri-Agency jointly administers the Canadian Graduate Scholarships at the master's (CGS-M) and doctoral (CGS-D) level, the Vanier scholarship, and agency-specific awards including the Post Graduate Scholarship for doctoral students (PGS-D), SSHRC Doctoral Fellowships (SSHRC-DF), and Doctoral Foreign Study Award (DFSA) respectively.

A comparison of data between the Canadian census and federal scholarship recipients reveals that the distribution of individuals from under-represented groups (URGs) with a master's or doctoral degree, including women, visible minorities, Indigenous peoples, and people with disabilities, is not being proportionately represented in the federal award processes (Table 1).

This discrepancy suggests there are barriers that limit individuals in URGs from applying to Tri-Agency scholarships.
In April 2021, the Tri-Agency released a 2018-2025 action plan to address systemic barriers and increase equity, diversity, and inclusion (EDI) in the postsecondary research ecosystem (NSERC 2021). However, their proposed initiatives are long-term projects and immediate actions are required to increase the equity of graduate student funding for URGs.

We propose three changes to the federal granting process regarding the eligibility, evaluation, and value of the federal graduate awards to make them more equitable for URGs; however, we exclude the DFSA in this analysis because of the large difference in its eligibility criteria (CIHR 2021a). Our proposed changes focus on making federal scholarships more accessible and increasing the participation and retention of URGs in research. These mechanisms ultimately support the Tri-Agency's efforts to redefine research excellence, better support early career researchers from URGs, and address opportunities for action, which were not included in the published plan.

\section{Recommendations}

i. Broadening eligibility duration for doctoral awards A key determinant of eligibility for Canadian federal doctoral awards is the length of enrollment in a program. In most cases, the eligibility duration for these awards is limited to the first two to three years of doctoral study (NSERC 2020b). However, there are inconsistencies in the duration of application eligibility between the different Tri-Agency administered awards, as well as agency-specific awards (Table 2).

\begin{tabular}{|l|c|c|c|c|c|c|}
\hline & \multicolumn{3}{|c|}{ NSERC's 2020 Competition } & \multicolumn{2}{c|}{ 2016 census data from Statistics Canada } \\
& Statistics & & Men & Other \\
\hline & Women & Men & Other & Women & N/A \\
\hline Doctoral & $39 \%$ & $56 \%$ & $5 \%$ & $56 \%$ & $44 \%$ & N/A \\
\hline Master's & $29 \%$ & $54 \%$ & $17 \%$ & $54 \%$ & $46 \%$ & Disability \\
\hline & $\begin{array}{c}\text { Visible } \\
\text { Minority }\end{array}$ & Indigenous & Disability & $\begin{array}{c}\text { Visible } \\
\text { Minority }\end{array}$ & Indigenous & N/A \\
\hline Doctoral & $28 \%$ & $2 \%$ & $4 \%$ & $37 \%$ & $1 \%$ & N/A \\
\hline Master's & $14 \%$ & $1 \%$ & $2 \%$ & $39 \%$ & $1 \%$ & $1 \%$ \\
\hline
\end{tabular}

Table 1: Distribution of graduate student awards by NSERC in 2020 (NSERC 2020c) and percentage of the Canadian population identified as holding a master's and/or doctoral degree from URGs in 2016 (Statistics Canada 2016a, 2016b). $\mathrm{N} / \mathrm{A}$ indicates the data was not available in the 2016 census. 


\begin{tabular}{|c|c|c|}
\hline $\begin{array}{l}\text { Federal } \\
\text { funding } \\
\text { agency }\end{array}$ & $\begin{array}{l}\text { Award details (title, } \\
\text { annual value, } \\
\text { duration) }\end{array}$ & Duration of eligibility for applicants \\
\hline \multirow[t]{3}{*}{ Tri-Agency } & $\begin{array}{l}\text { CGS-M, } \\
\$ 17,500 \text { per year, } \\
1-2 \text { years }\end{array}$ & $\begin{array}{l}\text { - } 0 \text { to } 12 \text { months of full-time study in graduate program by } \\
\text { December } 31 \text { of the application year. }\end{array}$ \\
\hline & $\begin{array}{l}\text { CGS-D, } \\
\$ 35,000 \text { per year, } \\
3 \text { years }\end{array}$ & $\begin{array}{l}\text { - } 0 \text { to 24-months of full-time study in doctoral program by } \\
\text { December 31, if previously enrolled in a master's } \\
\text { program. } \\
0 \text { to } 36 \text {-months of full-time study by December } 31 \text { if } \\
\text { enrolled in a joint program (e.g. MD/PhD) or if enrolled } \\
\text { directly from a bachelor's. }\end{array}$ \\
\hline & $\begin{array}{l}\text { Vanier, } \\
\$ 50,000 \text { per year, } \\
3 \text { years }\end{array}$ & $\begin{array}{l}\text { - } 0 \text { to 20-months of full-time study in doctoral program by } \\
\text { May 1, if previously enrolled in a master's program. } \\
0 \text { to 32-months of full-time study in doctoral program by } \\
\text { May } 1 \text { if enrolled in a joint program (e.g. MD/PhD) or if } \\
\text { enrolled directly from a bachelor's. }\end{array}$ \\
\hline NSERC & $\begin{array}{l}\text { PGS-D, } \\
\$ 21,000 \text { per year, } \\
3 \text { years }\end{array}$ & - $\quad$ Same as CGS-D \\
\hline CIHR & $\begin{array}{l}\text { DFSA, } \\
\$ 30,000 \text { per year, } \\
3 \text { years }\end{array}$ & - $\quad$ Same as CGS-D \\
\hline SSHRC & $\begin{array}{l}\text { SSHRC-DF, } \\
\$ 20,000 \text { per year, } \\
\text { duration varies }\end{array}$ & $\begin{array}{l}\text { - } 0 \text { to } 48 \text {-months of full-time study in a doctoral program by } \\
\text { December } 31 \text { st. } \\
\text { - The award duration is scaled by the student's enrollment: } \\
\circ 0 \text { to } 12 \text {-months, } 48 \text {-month award } \\
\circ 12 \text { to } 24 \text {-months, } 36 \text {-month award } \\
\circ 24 \text { to } 36 \text {-months, } 24 \text {-month award } \\
\circ 36 \text { to } 48 \text {-months, } 12 \text {-month award }\end{array}$ \\
\hline
\end{tabular}

Table 2: The value, duration, and eligibility of students for the Canadian Federal Graduate Student Awards (CIHR 2021a; NSERC 2020b; SSHRC 2020; Vanier Canada Graduate Scholarships 2021). Award values are in Canadian dollars.

The Tri-Agency states that one of the intents of these federal awards is to provide students with the freedom in choosing a host institution, independent of funding availability (NSERC 2020b). Limiting applications to early-level Ph.D. students may be to prevent applicants from being outcompeted by experienced doctoral students. However, this may disadvantage students who are less familiar with the funding system when coming into graduate school (CIHR 2016), which reduces their overall window for planning and preparing a competitive application. Restricting eligibility to the first few years of enrollment results in evaluating student excellence on the basis of pre-doctoral academic accomplishments, which can be heavily confounded by systemic barriers faced by undergraduate students from historically URGs. The first few years of graduate studies are often dedicated to defining and developing one's project and its approach, while scientific achievements, such as manuscripts and collaborative efforts, build up over the final years of a doctoral degree (Roach and Sauermann 2017).

We recommend harmonizing the duration of eligibility for federal awards, with the SSHRC-DF serving as the basis for this criterion. This would give doctoral students up to four years to apply, with the award duration scaling based on the number of months of full-time enrollment (Table 2). To prevent awards from being disproportionately given to experienced doctoral students, the number of awarded scholarships should be proportional to the number of applicants from each year of their degree. 


\section{ii. Revaluating award criteria}

The current evaluation criteria of federal graduate awards vary between award types (Table 3), and the rationale behind this difference is unclear. The selection criteria based on "excellence" favors students with significant academic accomplishments during their undergraduate education. To meet these criteria, students need to work, often unpaid, in a research lab during their undergraduate studies. This disadvantages students who choose paid employment over volunteer experience, and even funded research positions can be insufficient to meet financial needs (Favaro and Hind-Ozan 2020).

The Tri-Agency should broaden its definition of "excellence" in academia by collectively adopting CIHR's commitment to developing a more inclusive concept of research excellence, as outlined in CIHR's Strategic Plan 2021-2031 (CIHR 2021b). Alternative experiences, including non-research work and volunteering within the community, help develop professional skills and should also be considered in applications. As well, NSERC, CIHR, and SSHRC are all signatories on the San Francisco Declaration on Research Assessment (DORA), which makes several recommendations for improving the evaluation of research output. The Tri-Agency has stated that the DORA recommendations align with their EDI Action Plan on reviewing the existing criteria for assessment of research excellence (NSERC 2019). DORA encourages funding agencies to consider the value of non-traditional outputs of research, such as datasets and software, and to measure scientific impact beyond publication metrics, such as its influence on policy (DORA 2021). Implementing these practices may encourage more individuals from URGs to apply to federal graduate awards.

Aligned with the objectives of the Tri-Agency's Action Plan to address this barrier, we recommend equally weighting the selection criteria across federal awards based on 1) Academic excellence; 2) Research ability and potential; and 3) Personal characteristics, interpersonal skills, and leadership. This will also make the eligibility criteria similar to that of the Vanier Award (Table 3).

Moreover, this equal weight of the criteria may encourage candidates (from historically URGs) who may have had numerous commitments outside of academics to apply. This may increase diversity and inclusivity within the pool of candidates.

This equal emphasis between the three main criteria would recognize the need for well-roundedness in a candidate. As well, over a third of graduate students do not pursue a full-time career in academia (Reithmeier et al. 2019), hence, demonstration of excellence in leadership and involvement in professional development and community engagement opportunities should reflect the diversity of goals and career outcomes of graduate students.

\section{iii. Standardizing award values}

Canadian federal graduate student awards vary greatly in value and length across disciplines (Table 2). A survey of Canadian astronomy graduate students on tuition and funding clearly depicted how graduate students throughout the country are facing various financial strains. In almost all cases, domestic students spend $90 \%$ of their income on tuition, housing, food, internet, and ancillary fees (Lavoie 2010). A second survey of over 1,100 graduate students and postdocs found that $79 \%$ wanted to increase the value of existing awards (SPE 2020). We recommend increasing award values across disciplines, and increasing the number of awards available, to better align with the current standard of living and increasing the number of awards available.

\begin{tabular}{|l|c|l|c|l|c|}
\hline \multicolumn{2}{|c|}{ CGS-M } & \multicolumn{1}{|c|}{ CGS-D / PGS-D / DFSA / SSHRC-DF } & \multicolumn{2}{c|}{ Vanier } \\
\hline Criteria & Weight & Criteria & Weight & Criteria & Weight \\
\hline Research potential & $30 \%$ & Research ability and potential & $50 \%$ & Research potential & $33 \%$ \\
\hline Academic excellence & $50 \%$ & Relevant experience and & $50 \%$ & Academic excellence & $33 \%$ \\
\cline { 2 - 6 } $\begin{array}{l}\text { Personal } \\
\text { characteristics and } \\
\text { interpersonal skills }\end{array}$ & $20 \%$ & & Leadership & $33 \%$ \\
within and beyond academia & & & \\
\hline
\end{tabular}

Table 3: Overview of the current selection criteria for "excellence" used in the evaluation of applications for selected federal awards. Proposed changes to the evaluation criteria for the CGS-M and CGS-D, PGS-D, SSHRC-DF are similar to what is currently used to assess applications for the Vanier Scholarship. 
In agreement with a survey of over 1,000 graduate students and post-doctoral fellows in Canada (SPE 2020), we suggest increasing award values to $\$ 21,000$ for CGS-M and $\$ 35,000$ for PGS-D and SSHRC-DF.

While the average tuition cost for graduate programs has increased by 1\% annually since 2006 (Statistics Canada 2021), the value of Canadian federal graduate awards has, unfortunately, been stagnant since 2003 (Naylor et al. 2017). Award values should increase on an annual basis with inflation rates and tuition fees to maintain the same level of support for students. For students living in large cities, standard federal awards should provide a top-up to help with the exorbitant costs of rent and housing. For example, the average graduate student at the University of Toronto-St. George Campus starting in 2020 spends $\$ 1,711.03$ (University of Toronto 2020) and $\$ 6,444$ (CMHC 2021) more on tuition and housing respectively than a student in 2003. When considering inflation alone, an award in 2003 worth $\$ 35,000$ is equivalent to $\$ 48,000$ today. At present, we recognize the impracticality of requesting award values be raised to such an extent; however, this highlights the lack of continued support graduate students have received over the past two decades.

Ultimately, standardizing award values provides increased financial security and stability for graduate student researchers. An annual increase of these awards, in line with inflation and increasing tuition fees, will prevent the awards from being devalued.

\section{Discussion}

The Government of Canada needs to reexamine graduate student funding through the Tri-Agency to create a more equitable research ecosystem. In turn, the Tri-Agency must develop new eligibility and award criteria and share these changes with students, supervisors, and application reviewers. Academic institutions need to encourage applications from all students, especially members of URGs. In turn, universities will see a direct benefit from well-funded and productive graduate students. Implementing these recommendations would also strengthen the Tri-Agency's signed support of DORA.

Our recommendations are dependent on increased funding to the Tri-Agency. Without a budget increase, the funds required to standardize award values to
$\$ 21,000$ (for master's students) and $\$ 35,000$ (for doctoral students) might result in fewer numbers of overall scholarships granted. It could also result in a reduction in funding for elite awards including the Vanier Award. While at present, this is the only federal award to which international graduate students are eligible, only $13 \%$ of awardees are foreign scholars (CIHR 2014).

If an increase in the budget for Tri-agency scholarships is not provided by the federal government, we recommend the Tri-Agency focuses on revaluating the award criteria. Pursuing recommendation one without a budget increase could mean that scholarships will become even more competitive since there would be more applications for the same number of scholarships. Awards including PGS-D and CGS-D currently operate under a quota system and only a designated number of applications per institution are accepted for the federal competition, with exemptions made for Indigenous scholars (NSERC 2020a). Therefore, if there are more applications to screen and process, the administrative burden would fall on each institution who might be hesitant to shoulder this increased workload.

\section{Conclusion}

Canadian federal scholarships provide graduate students with financial and research independence which significantly impacts their future academic careers. The current award system has many limitations, particularly in respect to its ability to adequately support equity, diversity, and inclusion in academia.

To address this, we recommend: 1 ) increasing the eligibility duration of the Tri-Agency awards to match that of the SSHRC doctoral awards, and distribute awards proportionate to the number of applicants in each enrollment bracket; 2) change the evaluation criteria used to grant these awards by equally weighting academic excellence, research potential, and personal and leadership experience; and 3) increase and standardize award values across the TriAgency. These recommendations are a step forward to reducing barriers and ensuring accessibility for all research students, especially for individuals from historically URGs. 


\section{References}

Canada Mortgage and Housing Corporation (CMHC). 2021. "Housing Market Information Portal". Government of Canada.

https://www03.cmhc-schl.gc.ca/hmippimh/en/TableMapChart/Table?TableId=2.2.11 \&GeographyId=2270\&GeographyTypeId=3\&Disp layAs $=$ Table $\&$ GeograghyName $=$ Toronto

Canada Research Coordinating Committee. 2020. "2019-20 Progress Report: Mobilizing Canadian Research". Government of Canada.

https://www.canada.ca/en/researchcoordinatingcommittee/services/publications/progressreports/2019-2020.html

CIHR. 2014. "Evaluation of the Vanier Canada Graduate Scholarships Program." Government of Canada. https://cihr-irsc.gc.ca/e/48761.html

CIHR. 2016. "Evaluation of the Canada Graduate Scholarships (CGS) Program, 2008-2013." Government of Canada. https://cihr-irsc.gc.ca/e/50081.html

CIHR. 2021a. "CIHR Health Research Training Award Programs." Government of Canada. https://cihr-irsc.gc.ca/e/50513.html.

CIHR. 2021b. "CIHR Strategic Plan 2021-2031." Government of Canada. https://cihr-irsc.gc.ca/e/52331.html.

DORA. 2021. "San Francisco Declaration on Research Assessment," American Society for Cell Biology. https://sfdora.org/read/.

Favaro, B. and Hind-Ozan E. 2020. "SciSpends: an exploratory survey investigating nonreimbursed expenses in biological sciences." FACETS 5(1): 989-1005. https://doi.org/10.1139/facets-2020-0026.

Ginther, D. K., Schaffer, W. T., Schnell, J., Masimore, B., Liu, F., Haak, L. L., \& Kington, R. 2011. "Race, ethnicity, and NIH research awards." Science 333(6045), 1015-1019. 10.1126/science.1196783

Government of Canada. 2018. "Canadian Federal Budget: Equality Growth - A Strong Middle Class." Government of Canada.

https://www.budget.gc.ca/2018/docs/plan/toctdm-en.html.

Lavoie, S. 2010. "A survey of graduate Astronomy funding throughout Canadian universities." Canadian Astronomical Society. https://casca.ca/?page id=5776.

Naylor, D. Birgeneau, R., Crago, M., Lazaridis, M., Malacrida, C., McDonald, A., Piper, M., Quirion, R., Wilson., A. 2017. "Investing in Canada's Future: Strengthening the Foundations of Canadian Research." http://www.sciencereview.ca/.
NSERC. 2019. "Canadian research funding organizations sign San Francisco Declaration on Research Assessment (DORA)." Government of Canada. https://www.nserc-crsng.gc.ca/MediaMedia/NewsDetailDetailNouvelles eng.asp?ID=1103.

NSERC. 2020a. "Canada Graduate Scholarships - Doctoral Program." Government of Canada. https://www.nserc-crsng.gc.ca/studentsetudiants/pg-cs/cgsd-bescd eng.asp

NSERC. 2020b. "Postgraduate Programs" Government of Canada.

https://www.nserc-crsng.gc.ca/StudentsEtudiants/PG-CS/index eng.asp.

NSERC. 2020c. "Competition Year 2020 statistics: Postgraduate Scholarships, Alexander Graham Bell Canada Graduate Scholarships, Postdoctoral Fellowships Program and Undergraduate Student Research Awards" Government of Canada. https://www.nserc-crsng.gc.ca/ doc/StudentsEtudiants/2020StatsScholarships e.pdf.

NSERC. 2021. "Tri-Agency EDI Action Plan for 2018-2025" Government of Canada. https://www.nserc-crsng.gc.ca/NSERCCRSNG/EDI-EDI/Action-Plan PlandAction eng.asp.

Reithmeier, R., O'Leary, L., Zhu, X., Dales, C., Abdulkarim, A., Aquil, A., Brouillard, l., Chang, S., Miller, S., Shi, W., Vu, N., Zou, C. 2019. "The 10,000 PhDs project at the University of Toronto: Using employment outcome data to inform graduate education." PloS one, 14(1), e0209898.

https://doi.org/10.1371/journal.pone.0209898.

Roach M, Sauermann H. 2017. "The declining interest in an academic career." PLoS ONE 12(9): e0184130. https://doi.org/10.1371/journal.pone.0184130

Science \& Policy Exchange (SPE). 2020. "Rethinking Federal Research Funding: Towards More Equitable Funding for Canada's Next Generation." https://www.sp-exchange.ca/rethinking-federalresearch-funding.

SSHRC. 2020. "SSHRC Doctoral Fellowships" Government of Canada.

https://www.sshrc-crsh.gc.ca/funding-

financement/programs-

programmes/fellowships/doctoral-doctorateng.aspx.

Statistics Canada. 2016a. "Census of Population." Statistics Canada Catalogue no. 98-400- X2016266. https://www12.statcan.gc.ca/censusrecensement/2016/dp-pd/dt-td/Index-eng.cfm.

Statistics Canada. 2016b. "Census of Population." Statistics Canada Catalogue no. 98-400-X2016274. https://www12.statcan.gc.ca/censusrecensement/2016/dp-pd/dt-td/Index-eng.cfm. 
Statistics Canada. 2021. "Table 37-10-0004-01 Canadian graduate tuition fees by field of study."

Government of Canada. https://doi.org/10.25318/3710000401-eng.

University of Toronto. 2020. "Prior Session Fee and Refund Schedules."

https://studentaccount.utoronto.ca/tuitionfees/sessions-archive/.

van den Besselaar, P., and Sandström, U. 2015. "Early career grants, performance, and careers: A study on predictive validity of grant decisions." Journal of Informetrics 9(4), 826-838.

https://doi.org/10.1016/j.joi.2015.07.011.
Vanier Canada Graduate Scholarships. 2021. "Eligibility". Government of Canada. https://vanier.gc.ca/en/eligibilityadmissibilite.html

Witteman, H. O., Hendricks, M., Straus, S., \& Tannenbaum, C. 2019. "Are gender gaps due to evaluations of the applicant or the science? A natural experiment at a national funding agency." The Lancet 393(10171), 531-540.

Sivani Baskaran is a Ph.D. candidate in environmental chemistry at the University of Toronto studying physical-chemical properties important to environmental chemical risk assessments. She has a passion for science, policy, and evidence-informed decision making and is a co-founder and past-president of the Toronto Science Policy Network.

Dhanyasri Maddiboina is a Ph.D. candidate at McMaster in chemical engineering and has a longstanding passion in advocating for graduate student education and development in the areas of science communication and science policy.

Jina J.Y. Kum is a Ph.D. candidate in the Department of Pathology and Laboratory Medicine at Western University. Her research investigates how diabetes affects stem cells and their niches within the bone marrow. Being keenly interested in science policy, Jina volunteers in the non-profit sector where her roles include writing articles about science, health research and policy.

Rebekah Reuben is a Ph.D. candidate in the Department of Psychology at the University of Toronto. Her research investigates the role estrogen loss contributes to sex differences in cognitive decline and Alzheimer's disease. Rebekah is a member of the Toronto Science Policy Network and is passionate about research and evidence-informed approaches for science and health policy.

Kaitlin Kharas is a Ph.D. candidate researching pediatric brain cancer at SickKids and the University of Toronto. She has a strong interest in promoting scientific literacy and is an executive member of the Toronto Science Policy Network.

Esmeralda Bukuroshi recently graduated from Faculty of Applied Science and Engineering at University of Toronto with a Ph.D. specializing in material development for organic photovoltaics. She is currently working at Ontario Health as a Senior Analyst, Innovation developing knowledge for provincial and ministry strategy directions related to innovative testing solutions for COVID-19.

Isabella Lim is a Ph.D. student in the Department of Psychology at the University of Toronto. Her research focuses on semantic memory and visual attention, specifically how categorical knowledge interacts with attentional processes. She is an executive member of the Toronto Science Policy Network.

Bipin Kumar Badri Narayanan is a Master's student in Computer Science at University of New Brunswick. His main research interests are Ethics and Bias in AI Systems. He volunteers in the non-profit sector, advocating for better policies for research and the post-secondary sector. Bipin plans to pursue his career in Public Policy and work in the Government.

\section{Acknowledgements}

The authors would like to thank the Toronto Science Policy Network and in particular Farah Qaiser for 
providing feedback on this work.

\section{Disclaimer}

The authors' views do not necessarily reflect those of their respective departments or institutions. 